\title{
POTENTIAL OF PSYCHROTROPHIC FUNGI ISOLATED FROM SIACHEN GLACIER, PAKISTAN, TO PRODUCE ANTIMICROBIAL METABOLITES
}

\author{
HASSAN, N. ${ }^{1, \dagger}-$ RAfiQ, M. ${ }^{1,2, \dagger}-$ HAYAT, M. ${ }^{1}$ - NADEEM, S. ${ }^{1}-$ Shah, A. A. ${ }^{1}-$ HASAN, F. ${ }^{1, *}$ \\ ${ }^{1}$ Applied Environmental \& Geomicrobiology Laboratory, Department of Microbiology \\ Quaid-i-Azam University, Islamabad 45320, Pakistan \\ ${ }^{2}$ Department of Microbiology, Abdul Wali Khan University, Mardan 23200, Pakistan \\ ${ }^{\top}$ These authors have contributed equally to this work. \\ *Corresponding author \\ e-mail:farihahasan@yahoo.com; phone:+92-51-9064-3065 \\ (Received $3^{\text {rd }}$ Nov 2016; accepted $6^{\text {th }}$ Apr 2017)
}

\begin{abstract}
This is the first study of recovery and characterization of fungi from ice, sediments and water samples collected from Siachen glacier, Himalaya Range, Pakistan. The isolation and Total Viable count $\left(\mathrm{CFU} / \mathrm{ml}\right.$ or g) was carried out by spread plate technique at $4^{\circ} \mathrm{C}$ and $15^{\circ} \mathrm{C}$. Seventeen fungal isolates were obtained and identified by analysis of $18 \mathrm{~S}$ rRNA ITS region. Most frequently isolated fungal isolates were Leotiomycetes sp., followed by Thelebolus, Penicillium, Cladosporium, Trichoderma, Periconia, Geomyces, Cryptococcus and Pueraria. All isolates were found halophilic and they were able to tolerate $\mathrm{NaCl}$ concentration up to $10-20 \%$. Some isolates showed viability at $45^{\circ} \mathrm{C}$ and most of the isolates were able to grow at $\mathrm{pH} 1-13$. All isolates were screened for their antimicrobial activity against clinically isolated bacterial and fungal strains but they showed good antimicrobial activity against Gram (+) bacteria. None of the fungal isolates inhibited Gram negative clinically isolated Escherichia coli and Klebsiella pneumonia but few were able to inhibit Gram positive bacterial and fungal strains. Fungal isolates were also screened for production of extracellular enzymes (amylase, cellulase, deoxyribonuclease, lipase, phosphatase and protease). Various isolates were good producers of cellulase, lipase and protease whereas only 2 out of 17 produced DNase and 4 produced phosphatase.
\end{abstract}

Keywords: non-polar glacier, psychrophilic fungi, enzymes, halophilic

\section{Introduction}

Psychrophilic fungi grow optimally at $15^{\circ} \mathrm{C}$ or lower but can also grow at temperature around $20^{\circ} \mathrm{C}$ or below, while psychrotrophic fungi grow well at temperature above $20^{\circ} \mathrm{C}$ (Maheswari, 2005; Robinson, 2001). Such type of fungi have been found and investigated in all major cold habitats, such as Antarctica (Blanchette et al., 2010), Arctic regions (Sonjak et al., 2006) and cold deep sea environments (Damare et al., 2006). Various fungi representing different genera and species e.g. Thelebolus microspores, Lemonniera, Tetracladium, have been isolated from different regions of Himalaya, India (Sati et al., 2014; Anupama et al., 2011).

The fungi in cold environments are facing numerous extreme limiting factors, including frequent freeze-thaw cycles, high salt concentration, low moisture content, extreme UV radiation and low nutrient availability (Robinson, 2001, McKenzie et al., 2003). To face such harsh conditions, fungi adapt themselves through various physiological and ecological mechanisms (Anupama et al., 2011). Although, several cold adaptive mechanisms of psychrophilic fungi have been described but it is assumed that a mixture of such mechanisms are employed by psychrophiles including production 
of antifreeze proteins, compatible solutes, trehalose and other freeze tolerance mechanisms (Robinson, 2001; Ruisi et al., 2007).

Psychrophilic and psychrotrophic fungi are capable of providing a large number of biotechnological and pharmaceutical applications. Psychrophilic fungi are capable of synthesizing secondary metabolites that are very unique to cold ecosystems (Rosa et al., 2008). Psychrophilic fungi are producers of cold shock and cold-acclimation proteins and enzymes (e.g. proteases, lipases and cellulases) that are widely used in various biotechnological fields (Gounot, 1991). These include cold-water detergents, food additives, flavor modifying agents and biosensors. The psychrophilic fungi can also be central to astrobiology as other psychrophiles are (Montes-Hugo et al., 2009).

Antibiotic resistant pathogens emerge faster than the rate of discovery of new antibiotics. Extended spectrum beta-lactamase (ESBL) producing Enterobacteriaceae, vancomycin resistant Enterococci sp. and methicillin-resistant Staphylococcus aureus (MRSA) are all examples of the pathogens that are difficult to treat due to lack of effective antibiotics. It is important to look for new antibiotics from extreme sources that have not yet been explored for this purpose. We need to investigate antibiotics production from new extreme and unexplored sites against both multi-drug resistant bacteria and fungi.

This study was commenced to investigate the presence of psychrophilic fungi from from Siachen glacier, Pakistan, as well as to evaluate various physiological parameters, antimicrobial activity and extracellular enzyme production.

\section{Materials and methods}

\section{Sampling}

Siachen glacier is the second longest $(70 \mathrm{~km})$ non-polar glacier in the world, located in the Himalaya Range. Total width of the glacier is between $2-8 \mathrm{~km}$ and the total area is less than $1,000 \mathrm{~km}^{2}$. Three different forms of samples (glacier ice, sediments and water) were collected from Siachen glacier, Pakistan, using sterile bottles following standard microbiological protocols and were transported on ice to Microbiology Research Laboratory, Department of Microbiology, Quaid-i-Azam University, Islamabad, within $24 \mathrm{~h}$ of sampling for further processing. $\mathrm{pH}$ of all the samples was neutral (7.0), whereas, temperature of sediments and water was $1{ }^{\circ} \mathrm{C}$ and ice at $-3^{\circ} \mathrm{C}$.

\section{Isolation of fungi}

The general purpose fungal medium, Sabouraud Dextrose Agar (SDA) and Potato Dextrose Agar (PDA) were used for the isolation of fungi. Isolation was carried out at two temperatures, $4^{\circ} \mathrm{C}$ and $15^{\circ} \mathrm{C}$. After 4 weeks of incubation, colony forming units (CFU) were counted and expressed as $\mathrm{CFU} / \mathrm{mL}$ for ice and melt water samples as well as $\mathrm{CFU} / \mathrm{g}$ for the sediment sample.

\section{Morphology}

The colony morphology of pure fungal cultures was observed on SDA, with respect to their colony color, texture, shape etc. (front and reverse of the colony). Microscopy of the fungal isolates was done using lacto-phenol cotton blue staining method (40x). 


\section{DNA extraction, sequencing and phylogenetic analysis}

Fungal DNA extraction was performed according to protocol described earlier (Rosa et al., 2009). The primers ITS1 (5'-TCCGTAGGTGAACCTGCGG-3') and ITS4 (5'TCCTCCGCTTATTGATATGC-3') were used for amplification of ITS regions (ITS15.8S ITS2). The PCR conditions were: initial denaturation at $94^{\circ} \mathrm{C}$ for $1 \mathrm{~min}, 30$ cycles of denaturation at $94^{\circ} \mathrm{C}$ for $30 \mathrm{sec}$, annealing at $55^{\circ} \mathrm{C}$ for $30 \mathrm{sec}$, and extension at $72^{\circ} \mathrm{C}$ for $1 \mathrm{~min}$, followed by $10 \mathrm{~min}$ final extension at $72^{\circ} \mathrm{C}$. PCR products were run on agarose gel with DNA ladder to confirm the correct size of the gene. The PCR products were sent to Macrogen (Macrogen Inc. Seoul, Korea) for sequencing of $18 \mathrm{~S}$ rRNA gene. The obtained sequences were analysed through Chromas Lite and were further examined by comparing the nucleotide sequences available in NCBI database (Thompson et al., 1997). The evolutionary history was inferred via the Maximum Likelihood method based on Tamura-Nei model (Tamura and Nei, 1993). The phylogenetic tree was created in MEGA software using Maximum Likelihood method (Tamura and Nei, 1993) at the bootstrap value 1000.

\section{Evaluation of physiological parameters}

Growth tolerance of all the fungal isolates to varying temperature (4 to $50^{\circ} \mathrm{C}$ ), $\mathrm{pH}$ ( $\mathrm{pH} 1$ to 13$)$ and salt concentration $(\mathrm{NaCl}$ up to 26\%), was checked on SDA using 10 day old colonies, following incubation at $4{ }^{\circ} \mathrm{C}$ and $15^{\circ} \mathrm{C}$ for 10 days.

\section{Antimicrobial activity evaluation}

Clinically isolated human pathogens (multi-drug resistant) such as E. coli (MDR), Klebsiella pneumonia (MDR), Staphylococcus aureus (MDR), Staphylococcus sp., Enterococcus sp. (VRE), Candida albicans and Aspergillus niger were used as target subjects. Point inoculation method was used for evaluation of antimicrobial activity. Using a sterile wire loop, a pure test microbial colony was transferred into the test tube containing normal saline and adjusted the turbidity with $0.5 \mathrm{McFarland}$ solution as the standard. A sterile cotton swab was used to prepare homogenous lawn on Potato Dextrose Agar and Tryptic Soy Agar. A small portion of each fungal mycelium was inoculated on plates containing bacterial lawn.

\section{Extracellular enzymes}

Fungal isolates were screened for the production of extracellular enzymes including amylase, deoxyribonuclease, lipase, cellulose, protease and phosphatase according to protocols described by Hankin and Anagnostakis (1975) and Pikovskaya (1948). The isolates were screened for cellulolytic activity by using carboxymethylcellulose (CMC) as a substrate. For cellulolytic activity, the plates were flooded with $0.5 \%$ Congo red solution for 10 minutes, then washed with distilled water and flooded with $1 \mathrm{M} \mathrm{NaCl}$. The clearing zone around the colony was observed. All qualitative extracellular enzyme activities were assayed at 4 and $15^{\circ} \mathrm{C}$.

\section{Results}

In the current study, 17 fungal strains were isolated from all the three samples (glacial ice, water and sediments) of the Siachen glacier, Pakistan, by culturing at two 
temperatures $4^{\circ} \mathrm{C}$ and $15^{\circ} \mathrm{C}$. The fungal $\mathrm{CFU} / \mathrm{g} / \mathrm{mL}$ in sediments was highest at both temperatures followed by water and ice (Table 1$)$.

Table 1. Total viable count (CFU/mL/g) of fungal isolates at $15^{\circ} \mathrm{C}$ and $4^{\circ} \mathrm{C}$

\begin{tabular}{ccc}
\hline Temperature $\left({ }^{\circ} \mathbf{C}\right)$ & Samples & CFU/mL/g \\
\hline \multirow{2}{*}{15} & Glacier ice & $3.0 \times 10^{1}$ \\
& Glacier water & $4.0 \times 10^{1}$ \\
& Glacier sediment & $3.75 \times 10^{2}$ \\
& Glacier ice & $1.5 \times 10^{1}$ \\
4 & Glacier water & $2.0 \times 10^{2}$ \\
& Glacier sediment & $4.5 \times 10^{2}$ \\
\hline
\end{tabular}

\section{Morphological evaluation}

Fungal isolates had different colony morphology, mostly were of tough and mucoid texture while powdery and cottony texture was also observed. The microscopic features of the fungal isolates were observed in terms of fruiting bodies, hyphal structure (i.e. branched or single hyphae, septate or aseptate), spore, spore shape (circular, oval, rod or others). The macroscopic and microscopic characteristics of different fungal isolates on the SDA are given in Supplementary Table 1.

\section{Molecular characterization}

Based on sequencing of the ITS regions (ITS1 - ITS4), all the fungal isolates were found to belong to varied taxonomic groups. The phylogenetic tree, describing evolutionary relationships among all fungal isolates is given in Figure 1 and the resemblance index of strains with respective homology of the isolates is summarized in Table 2. Majority of the fungal isolates showed close similarity with the respective homologous species between $99-100 \%$ and only LS3 showed 97\% similarity with Thelebolus microspores.

\section{Physiological parameters}

Optimum temperature for all the isolates was between 4 and $15^{\circ} \mathrm{C}$ but many fungal isolates showed growth up to $37^{\circ} \mathrm{C}$ while few were able to grow at $45^{\circ} \mathrm{C}$ as well but none of them displayed growth at $50^{\circ} \mathrm{C}$ (Table 3). However, there was less growth at 37 and $45^{\circ} \mathrm{C}$. Fungal isolates exhibited growth at wide range of $\mathrm{pH}$. Optimum $\mathrm{pH}$ for all fungal isolates was observed between 5 and 8. Most of the isolates were able to grow at $\mathrm{pH} 2-13$, while 6 isolates could also grow at $\mathrm{pH} 1$. Towards alkaline range, all the isolates tolerated $\mathrm{pH}$ up to 13. Salt tolerance of the fungal isolates was between 2 and $20 \%$ of $\mathrm{NaCl}$. Based on these results, the isolates were considered as cold, $\mathrm{pH}$ and salt tolerants.

\section{Antimicrobial activity evaluation}

Fungal isolates exhibited good antibacterial activity as compared to antifungal activity (Table 4). Mostly, they exhibited antimicrobial activity against Gram positive bacteria (6 showed activity against Staphylococcus sp., 5 against Staphylococcus aureus, and 1 against 
Enterococcus sp.), while only 1 fungal isolates showed antifungal activity against Candida albicans and Aspergillus niger, respectively. None of the isolates exhibited antibacterial activity against Gram negative bacteria (E. coli and Klebsiella pneumoniae).

Table 2. The resemblance index of strains with respective homology of the fungal isolates

\begin{tabular}{|c|c|c|c|c|}
\hline Isolates & $\begin{array}{l}\text { Accession } \\
\text { No. }\end{array}$ & $\begin{array}{l}\text { Homologous species } \\
\text { [accession number] }\end{array}$ & $\begin{array}{l}\text { ID } \\
(\%)\end{array}$ & $\begin{array}{c}\text { No of } \\
\text { analysed bp }\end{array}$ \\
\hline $\mathbf{H S}_{\mathbf{1}}$ & KR676355 & Geomyces pannorum |HQ703417.1| & 100 & 488 \\
\hline $\mathbf{H S}_{2}$ & KR676356 & Leotiomycetes sp |KC514892.1| & 99 & 480 \\
\hline $\mathbf{H S}_{3}$ & KR676357 & Pueraria montana |EF432795.1| & 100 & 539 \\
\hline $\mathbf{H S}_{4}$ & KR676358 & Thelebolus microspores |KM822751.1| & 100 & 481 \\
\hline $\mathbf{H S}_{5}$ & KR676359 & Penicillium brevicompactum |KF990149.1| & 100 & 517 \\
\hline $\mathbf{H S}_{6}$ & KR676360 & Cladosporium uredinicola |KM513616.1| & 99 & 491 \\
\hline $\mathbf{H S}_{7}$ & KR676361 & Trichoderma viride |DQ093772.1| & 100 & 500 \\
\hline $\mathbf{H S}_{\mathbf{8}}$ & KR676362 & Pueraria montana |EF432796.1| & 100 & 537 \\
\hline $\mathbf{H S}_{9}$ & KR676363 & Leotiomycetes sp |KC514892.1| & 99 & 480 \\
\hline $\mathbf{L S}_{\mathbf{1}}$ & KR676364 & Leotiomycetes sp |KC514892.1| & 99 & 480 \\
\hline $\mathbf{L S}_{2}$ & KR676365 & Pueraria montana |EF432796.1| & 100 & 539 \\
\hline $\mathbf{L S}_{\mathbf{3}}$ & KR676366 & Thelebolus microspores |KM822751.1| & 97 & 520 \\
\hline $\mathbf{L S}_{4}$ & KR676367 & Periconia sp |KF907244.1| & 99 & 492 \\
\hline $\mathbf{L S}_{5}$ & KR676368 & Thelebolus microspores |KM822751.1| & 99 & 512 \\
\hline $\mathbf{L S}_{6}$ & KR676369 & Leotiomycetes sp |KC514892.1| & 100 & 481 \\
\hline $\mathbf{L S}_{7}$ & KR676370 & Cryptococcus albidus |KP131887.1| & 99 & 532 \\
\hline $\mathbf{L S}_{\mathbf{8}}$ & KR676371 & Thelebolus ellipsoideus |KM816688.1| & 100 & 490 \\
\hline
\end{tabular}

Table 3. Growth responses of the fungal isolates to temperature, $\mathrm{pH}$ and the salt

\begin{tabular}{|c|c|c|c|}
\hline Isolates & Temperature $\left({ }^{\circ} \mathrm{C}\right)$ range & pH range & Salt range $(\%)$ \\
\hline $\mathbf{H S}_{1}$ & $4-37$ & $2-13$ & $2-16$ \\
\hline $\mathbf{H S}_{2}$ & $4-37$ & $2-13$ & $2-16$ \\
\hline $\mathbf{H S}_{3}$ & $4-37$ & $2-13$ & $2-18$ \\
\hline $\mathbf{H S}_{4}$ & $4-37$ & $1-13$ & $2-16$ \\
\hline $\mathbf{H S}_{5}$ & $4-37$ & $1-13$ & $2-20$ \\
\hline $\mathbf{H S}_{6}$ & $4-37$ & $2-13$ & $2-18$ \\
\hline $\mathbf{H S}_{7}$ & $4-37$ & $2-13$ & $2-18$ \\
\hline $\mathbf{H S}_{8}$ & $4-45$ & $1-13$ & $2-16$ \\
\hline $\mathbf{H S}_{9}$ & $4-37$ & $2-13$ & $2-16$ \\
\hline $\mathbf{L S}_{1}$ & $4-37$ & $2-13$ & $2-16$ \\
\hline $\mathbf{L S}_{\mathbf{2}}$ & $4-37$ & $1-13$ & $2-16$ \\
\hline $\mathbf{L S}_{\mathbf{3}}$ & $4-45$ & $1-13$ & $2-18$ \\
\hline $\mathbf{L S}_{4}$ & $4-37$ & $1-13$ & $2-10$ \\
\hline $\mathbf{L S}_{5}$ & $4-45$ & $2-13$ & $2-14$ \\
\hline $\mathbf{L S}_{\mathbf{6}}$ & $4-37$ & $2-13$ & $2-18$ \\
\hline $\mathbf{L S}_{7}$ & $4-45$ & $2-13$ & $2-16$ \\
\hline $\mathbf{L S}_{8}$ & $4-37$ & $2-13$ & $2-14$ \\
\hline
\end{tabular}




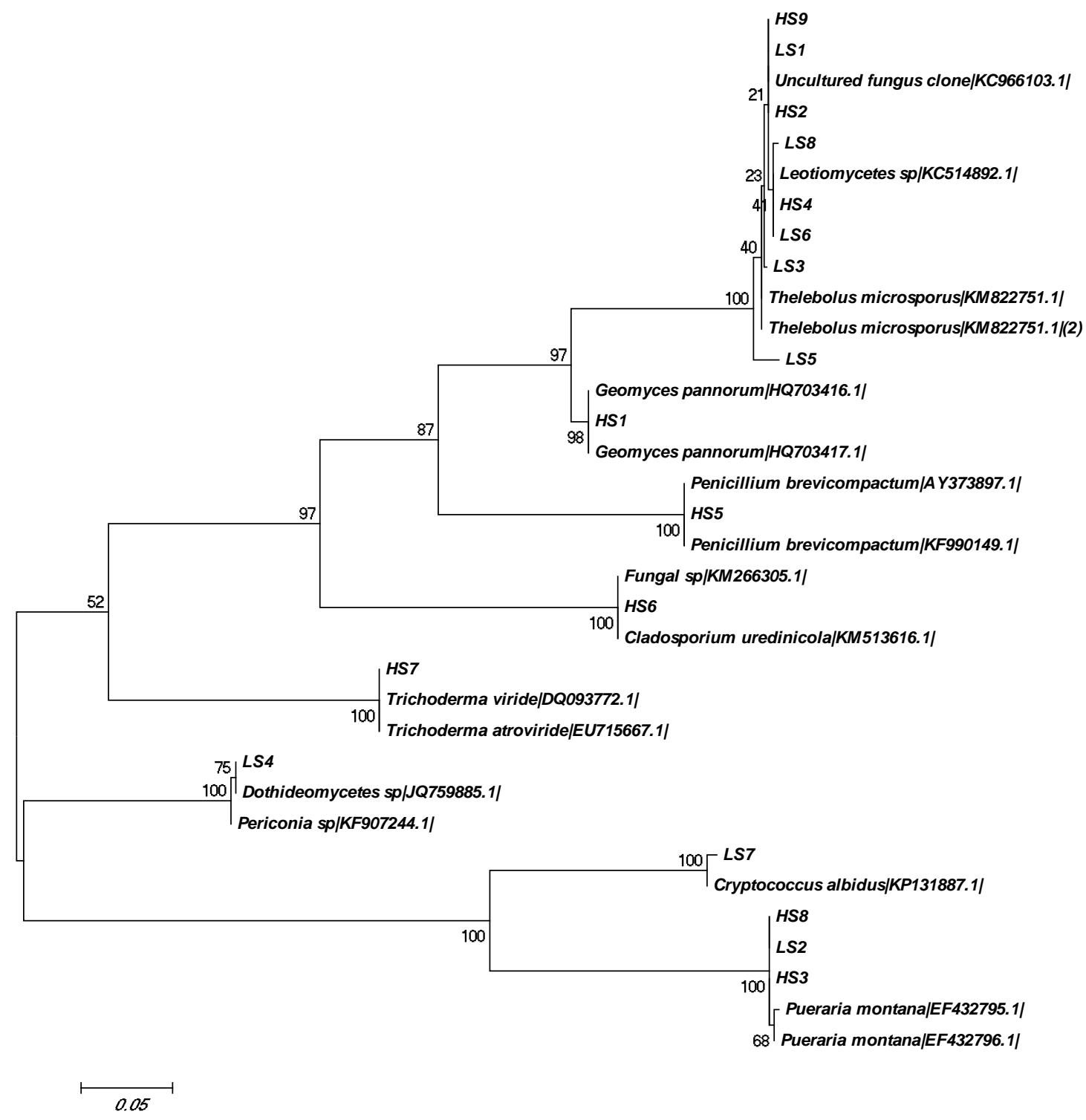

Figure 1. Molecular Phylogenetic analysis by Maximum Likelihood method

\section{Extracellular enzyme production}

The fungal isolates were good producers of lipase and cellulase. Out of 17 fungal species, 5 exhibited positive amylolytic activity, 12 showed cellulosic activities and only 2 isolates showed positive production for DNase (Table 5). While, 14 fungal isolates exhibited lipolytic activity, 5 isolates were found positive by exhibiting phosphate solubilizing activity and only 8 isolates showed proteolytic activity. The studies clearly demonstrated that fungal isolates were capable of producing a wide range of cold-active extracellular enzymes. 
Table 4. Antibacterial and antifungal activity of the fungal isolates by point inoculation

\begin{tabular}{|c|c|c|c|c|c|c|c|}
\hline \multirow[t]{2}{*}{ Isolates } & \multicolumn{5}{|c|}{ Bacteria } & \multicolumn{2}{|c|}{ Fungi } \\
\hline & $\begin{array}{c}E . \\
\text { coli }\end{array}$ & $\begin{array}{c}\text { Klebsiella } \\
\text { pneumoniae }\end{array}$ & $\begin{array}{c}S . \\
\text { aureus }\end{array}$ & $\begin{array}{c}\text { Staphylococcus } \\
\text { sp. }\end{array}$ & $\begin{array}{c}\text { Enterococcus } \\
\text { sp. }\end{array}$ & $\begin{array}{c}\text { Aspergillus } \\
\text { niger }\end{array}$ & $\begin{array}{l}\text { Candida } \\
\text { albicans }\end{array}$ \\
\hline $\mathbf{H S}_{1}$ & - & - & +++ & +++ & ++ & - & - \\
\hline $\mathbf{H S}_{2}$ & - & - & + & ++ & - & - & - \\
\hline $\mathbf{H S}_{3}$ & - & - & - & - & - & - & - \\
\hline $\mathbf{H S}_{4}$ & - & - & - & - & - & - & - \\
\hline $\mathbf{H S}_{5}$ & - & - & - & - & - & ++ & ++ \\
\hline $\mathbf{H S}_{6}$ & - & - & - & - & - & - & - \\
\hline $\mathbf{H S}_{7}$ & - & - & - & - & - & - & - \\
\hline $\mathbf{H S}_{8}$ & - & - & - & - & - & - & - \\
\hline HS $_{9}$ & - & - & + & ++ & - & - & - \\
\hline $\mathbf{L S}_{1}$ & - & - & + & ++ & - & - & - \\
\hline $\mathbf{L S}_{2}$ & - & - & - & - & - & - & - \\
\hline $\mathbf{L S}_{\mathbf{3}}$ & - & - & - & - & - & - & - \\
\hline $\mathbf{L S}_{4}$ & - & - & - & ++ & - & - & - \\
\hline $\mathbf{L S}_{5}$ & - & - & - & - & - & - & - \\
\hline $\mathbf{L S}_{6}$ & - & - & - & - & - & - & - \\
\hline $\mathbf{L S}_{7}$ & - & - & ++ & ++ & - & - & - \\
\hline $\mathbf{L S}_{8}$ & - & - & - & - & - & - & - \\
\hline
\end{tabular}

Table 5. Production of various extracellular enzymes by fungal isolates

\begin{tabular}{|c|c|c|c|c|c|c|}
\hline \multirow[t]{2}{*}{ Isolates } & \multicolumn{6}{|c|}{ Enzymes } \\
\hline & Amylase & Cellulase & DNase & Lipase & Phosphatase & Protease \\
\hline $\mathbf{H S}_{1}$ & - & + & - & ++ & - & - \\
\hline $\mathbf{H S}_{2}$ & - & + & - & ++ & - & + \\
\hline $\mathbf{H S}_{3}$ & - & - & - & + & - & - \\
\hline $\mathbf{H S}_{4}$ & + & + & - & + & + & - \\
\hline $\mathbf{H S}_{5}$ & + & - & + & - & + & - \\
\hline $\mathrm{HS}_{6}$ & - & ++ & - & - & - & - \\
\hline $\mathbf{H S}_{7}$ & - & + & - & + & - & + \\
\hline $\mathbf{H S}_{8}$ & + & + & + & + & - & - \\
\hline $\mathbf{H S}_{9}$ & - & + & - & ++ & - & + \\
\hline $\mathbf{L S}_{1}$ & - & + & - & ++ & - & + \\
\hline $\mathbf{L S}_{2}$ & - & - & - & + & - & - \\
\hline $\mathbf{L S}_{\mathbf{3}}$ & + & ++ & - & - & - & ++ \\
\hline $\mathbf{L S}_{4}$ & - & + & - & + & + & + \\
\hline $\mathbf{L S}_{5}$ & - & - & - & ++ & - & - \\
\hline $\mathbf{L S}_{6}$ & + & + & - & + & + & - \\
\hline $\mathbf{L S}_{7}$ & - & + & - & ++ & - & ++ \\
\hline $\mathbf{L S}_{8}$ & - & - & - & ++ & + & ++ \\
\hline
\end{tabular}




\section{Discussion}

The main purpose of our study was to isolate and characterize psychrophilic fungi from Siachen glacier, Pakistan. The existence of psychrophilic fungi in this glacier has not been explored previously. In this study, 17 fungal strains were isolated at two temperatures $4^{\circ} \mathrm{C}$ ( 8 isolates) and $15^{\circ} \mathrm{C}$ (9 isolates) from glacial sediments (Damare, 2006), ice and water (Sati et al., 2014). After microscopic, morphological and molecular analysis (18S rRNA sequencing), it has been found that our fungal isolates belonged to 1 fungal genera, 1 family and 1 class. Major fungal isolates belonged to class Leotiomycetes followed by genus Thelebolus (Sonjak et al., 2006), Pueraria (Blanchette et al., 2010), Penicillium, Cladosporium, Trichoderma, Periconia, Geomyces and Cryptococcus (Maheswari, 2005).

The genus Geomyces (formerly known as Chrysosporium pannorum), frequently reported keratinophilic and psychrophilic fungus from Arctic, Alpine, temperate and Antarctic regions (Vishniac, 1996; Mercantini et al., 1989). In Antarctica, G. pannorum was isolated from thalli of seaweeds (Loque et al., 2010), as an endophyte (Rosa et al., 2010) and is associated with mosses (Tosi et al., 2002). According to Montemartini et al. (Montemartini et al., 1993), the genus Thelebolus, mainly Thelebolus microsporus, has been isolated as predominant genus from Arctic and Antarctic climate zones. The genus Penicillium has the ability to tolerate low temperature environments but in fact, many species demonstrated by their growth on food preserved in refrigerators (Pitt and Hocking, 1990) or are isolated from alpine, tundra (Domsch et al., 1980). Penicillium species have been identified from soils, lakes, historic woodlands and macroalgal thalli in Antarctical regions (Loque et al., 2010). In addition, Cryptococcus genus reported from soil from Southern Victoria Land and other locations in Antarctica (Adams et al., 2006; Thomas-Hall et al., 2002). The other genera (Leotiomycetes, Cladosporium, Trichoderma, Periconia) have been reported and isolated from various polar and nonpolar cold habitats by other authors (Laura et al., 2013; Kostadinova et al., 2009).

In the present study, the fungal isolates showed great tolerance against different physiological parameters (temperature, $\mathrm{pH}$ and salt). The effects of $\mathrm{pH}$ on fungal growth were variable (from $\mathrm{pH} 1$ to $\mathrm{pH} 13$ ). Most of fungal isolates grow best over a $\mathrm{pH}$ range of 5-8. However, their growth was slow at pH extremes. Recca and Mrak (1952) and Battley and Bartlett (1966) found some of the fungal strains grown at $\mathrm{pH} 1.5$ and $\mathrm{pH} 9$. In addition, several fungi from cold habitats have been reported for their growth at both acidic and alkaline pH (Dhakar et al., 2014; Grzhimaylo et al., 2013). Most of the fungi were psychrotrophic in nature by growing at temperatures at $4-37^{\circ} \mathrm{C}$. However, some of fungal isolates were able to grow outside this range i.e. at $45^{\circ} \mathrm{C}$. Our results are supported by Zucconi et al. (1996), who isolated a thermotolerant-mesophilic fungal species from Victoria Land, Antarctica, having the ability to grow at $45^{\circ} \mathrm{C}$. Azmi and Seppelt (1997) reported many fungal genera that show growth in between $4-35^{\circ} \mathrm{C}$. The isolates in the present study showed growth up to $20 \%$ of $\mathrm{NaCl}$ thus showed halophilic nature. Kochkina et al. (2007) isolated a psychrophilic isolate of Geomyces from cryopegs. The isolate was capable of growth at up to $10 \% \mathrm{NaCl}$ concentration. Penicillium notatum and P. Chrysogenum isolated from sandy soil of Al-Ain area, U.A.E, were reported to tolerate $\mathrm{NaCl}$ up to $20 \%$ (El-Mougith, 1993). Greiner et al. (2013) isolated different fungal strains from salt mine in Berchtesgaden, Bavaria, Germany. Among them, a new fungal species Phialosimplex salinarum was able to grow in the presence of $25 \%$ of salts. 
In this study, the fungal isolates were screened for their antibacterial and antifungal activities against clinically isolated bacterial and fungal human pathogens. Although, their bactericidal and fungicidal activities were not very effective but some of our isolates showed antimicrobial activity against Gram (+) bacterial and fungal strains. Fungi from cold habitats have not yet been reported against clinically isolated multidrug resistant bacterial and fungal strains but fungi from other habitats have been extensively screened for this purpose and numerous antibiotics are being produced and commercially available. As the resistance against many antibiotics is increasing day by day, therefore new more effective antibiotics are the need of the day. Svahn et al. (2012) and Suay et al. (2000) have tested different filamentous fungi and yeasts against various human clinical pathogens (including MDR as well) and laboratory controls. Brunati et al. (2009) screened 160 filamentous fungi and 171 yeasts against bacterial and fungal human pathogens but none of them was MDR. It is evident from our results that MDR and resistant clinical isolates were inhibited. Metabolites from these fungal isolates can be characterized further.

Moreover, fungal isolates were checked for the production of extracellular enzymes. Generally, fungal isolates were good producers of lipase, protease and cellulase. Singh et al. (2012) has reported production of amylase, cellulase, phosphatase and pectinase enzymes at $4^{\circ} \mathrm{C}$ and $20^{\circ} \mathrm{C}$ from various filamentous fungi in Ny-Alesund, Spitsbergen. Thelebolus microspore has been found a good producer of amylase, lipase and chitinase enzymes from Larsemann Hills, Antarctica (Singh et al., 2014). Our results are also supported by Fenice et al. (1997) who screened 33 fungal strains for production of various extracellular enzymes, isolated from various sites of Victoria Land (continental Antarctica).

\section{Conclusions}

In our study, Siachen glacier was studied for the first time to look for the existence of fungi. Seventeen fungal isolates were isolated and identified through $18 \mathrm{~S}$ rRNA sequencing. Majority of the fungal isolates belonged Leotiomycetes, followed by Thelebolus, Penicillium, Cladosporium, Trichoderma, Periconia, Geomyces, Cryptococcus and Thelebolaceae family. Some fungal isolates showed growth in the presence of $26 \%$ of salt, at $\mathrm{pH} 1$ to 13 and at temperature $4^{\circ} \mathrm{C}$ to $45^{\circ} \mathrm{C}$. Many isolates showed good antimicrobial activity and were good producers of industrially important enzymes.

Acknowledgements. Higher Education Commission Pakistan. Help of MPhil students of AEG Lab.

Authors' Contribution: Noor Hassan and Muhmmad Rafiq carried out all the research work, wrote the study design, drafted the manuscript and contributed equally to the research work, Shaukat Nadeem and Muhammad Hayat contributed in sampling, and experimental work, Aamer Ali Shah drafted the manuscript, Fariha Hasan wrote the study design, supervised research work and critically revised the manuscript. All authors read and approved the final manuscript.

\section{REFERENCES}

[1] Maheswari, R. (2005): Fungal biology in the $21^{\text {st }}$ century. - Curr Scienc. 88:1406-1418.

[2] Robinson, C.H. (2001): Cold adaptation in Arctic and Antarctic fungi. - New Phytol. 151:341-53. 
[3] Blanchette, R.A., Held, B.W, Arenz, B.E., Jurgens, J.A., Baltes, N.J., Duncan, S.M., Farrell, R.L. (2010): An Antarctic hot spot for fungi at Shackleton's historic hut on Cape Royds. - Microbial Ecol. 60:29-38.

[4] Sonjak, S., Frisvad, J.C., Gunde-Cimerman, N. (2006): Penicillium mycobiota in Arctic subglacial ice. - Microbiol Ecol. 52:207-216.

[5] Damare, S., Raghukumar, C., Raghukumar, S. (2006): Fungi in deep-sea sediments of the Central Indian Basin. - Deep Sea Res. 53:14-27.

[6] Sati, S.C., Pathak, R., Belwal, M. (2014): Occurrence and distribution of Kumaun Himalayan aquatic hyphomycete. - Lemo Mycosphere. 5:545-553.

[7] Anupama, P.D., Praveen, K.D., Singh, R.K., Kumar, S., Srivastava, A.K., Arora, D.K. (2011): A psychrophilic and halotolerant strain of Thelebolus microsporus from Pangong Lake, Himalaya. - Mycosphere.2:601-609.

[8] McKenzie, R.L., Bjorn, L.O., Bai, A., Iayis, M. (2003): Changes in biologically active ultraviolet radiation reaching the Earth's Surface. - Photochem Photobiol Sci. 2:5-15.

[9] Ruisi, S., Barreca, D., Selbmann, L., Zucconi, L., Onofri, S. (2007): Fungi in Antarctica. - Rev Environmental Sci Biotechnol. 6:127-141.

[10] Rosa, M., Franz, S., Jean-Claude, M., Charles, G. (2008): Psychrophiles from Biodiversity to Biotechnology. - In: Jens, C. F. (ed.) Cold-adapted fungi as a source for valuable metabolites. Springer. pp. 381-384.

[11] Gounot, A.M. (1991): Psychropbilic and psyehrotrophic microorganisms. - Experientia. 42:1192-97.

[12] Montes-Hugo, M., Doney, S.C., Ducklow, H.W., Fraser, W., Martinson, D., Stammerjohn, S.E., Schofield, O. (2009): Recent changes in phytoplankton communities associated with rapid regional climate changes along the Western Antarctic Peninsula. Science. 323:1470-3.

[13] Rosa, L.H., Vaz, A.B.M., Caligiorne, R.B., Campolina, S., Rosa, C.A. (2009) Endophytic fungi associated with the Antarctic Grass Deschampsia Antarctica Desv. (Poaceae). - Polar Biol. 32:161-167.

[14] Thompson, J.D., Toby, J.G., Plewniak, F., Jeanmougin, F., Desmond, G.H. (1997) The CLUSTAL_X windows interface: flexible strategies for multiple sequence alignment aided by quality analysis tools. - Nucleic Acids Res. 25:4876-4882.

[15] Tamura, K., Nei, M. (1993): Estimation of the number of nucleotide substitutions in the control region of mitochondrial DNA in humans and chimpanzees. - Mol Biol Evol. 10:512-26.

[16] Hankin, L., Anagnostakis, S.L. (1975): The use of solid media for detection of enzyme production by fungi. - Mycol. 67:597-607.

[17] Pikovskaya, R.I. (1948): Mobilization of phosphorus in soil connection with the vital activity of some microbial species. - Microbiol. 17:362-370.

[18] Vishniac, H.S. (1996): Biodiversity of yeasts and filamentous microfungi in terrestrial Antarctic ecosystems. - Biodivers Conserv. 5:1365-1378.

[19] Mercantini, R., Marsella, R., Cervellati, M.C. (1989): Keratinophilic fungi isolated from Antarctic soil. - Mycopathol. 106:47-52.

[20] Loque, C.P., Medeiros, A.O., Pellizzari, F.M., Oliveira, E.C., Rosa, C.A., Rosa, L.H. (2010): Fungal community associated with marine macroalgae from Antarctica. - Polar Biol. 3:641-8. 
[21] Rosa, L.H., Vieira, M.D.L.A., Santiago, L.F., Rosa, C.A. (2010): Endophytic fungi community associated with the dicotyledonous plant Colobanthus quitensis (Kunth) Bartl. (Caryophyllaceae) in Antarctica. - FEMS Microbiol Ecol. 73:178-189.

[22] Tosi, S., Begona, C., Gerdol, R., Caretta, G. (2002): Fungi isolated from Antarctic mosses. - Polar Biol.25:262-268.

[23] Montemartini, A., Caretta, G., Del-Frate, G. (1993): Notes on Thelebolus microspores isolated in Antarctica. - Mycotaxon. 48:343-58.

[24] Pitt, J.I. (1990): Hocking AD. Fungi and Food Spoilage. $2^{\text {nd }}$ ed. - Aspen Publishers: Inc, Gaithersburg, pp. 234, 511, 512.

[25] Domsch, K.H., Gams, W., Anderson, T.H. (1980): Compendium of soil fungi. Academic Press, London. pp. 540-611.

[26] Adams, B.J., Bardgett, R.D., Ayres, E., Wall, D.H., Aislabie, J., Bamforth, S, et al. (2006): Diversity and distribution of Victoria Land biota. - Soil Biol Biochem. 38:30033018 .

[27] Thomas-Hall, S., Watson, K., Scorzetti, G. (2002): Cryptococcus statzelliae sp. nov. And three novel strains of Cryptococcus victoriae, yeasts isolated from Antarctic soils. - Int J Syst Evol Microbiol. 52:2303-2308.

[28] Laura, E., Godinho, F.V.M., Furbino, L.E., Santiago, I.F., Pellizzari, F.M., Yokoya, N.A, et al. (2013): Diversity and bioprospecting of fungal communities associated with endemic and cold-adapted macroalgae in Antarctica. - ISME Journal 7:1434-1451.

[29] Kostadinova, N., Krumova, E., Tosi, S., Pashova, Angelova, M. (2009): Isolation and identification of filamentous fungi from island Livingston, Antarctica. - Biotechnol Biotechnol Eq. 23:267-70.

[30] Recca, J., Mrak, E.M. (1952): Yeast occurring in citrus products. - Food Technology 6:450-454.

[31] Battley, E.H., Bartlett, E.J. (1966): A convenient $\mathrm{pH}$ gradient method for the determination of the maximum and minimum $\mathrm{pH}$ for microbial growth. - Antoine van Leeuwenhoek J Microbial Serol. 32:245-255.

[32] Dhakar, K., Sharma, A., Pandey, A. (2014): Cold, pH and salt tolerant Penicillium spp. inhabit the high altitude soils in Himalaya, India. - W J Microbiol Biotechnol. 30:13151324.

[33] Grzhimaylo, A.A., Debets, A.J.M., van-Diepeningen, A.D., Georgieva, M.L., Bilanenko, E.N. (2013): Sodiomyces alkalinus, a new holomorphic alkaliphilic ascomycete within the Plectosphaerellaceae. - Persoonia 31:147-58.

[34] Zucconi, L., Pagano, S., Fenice, M., Selbmann, L., Tosi, S., Onofri, S. (1996): Growth temperature preferences of fungal strains from Victoria Land, Antarctica. - Polar Biol. 16:53-61.

[35] Azmi, O.R., Seppelt, R.D. (1997): Fungi of the Windmill Islands, continental Antarctica. Effect of temperature, $\mathrm{pH}$ and culture media on the growth of selected microfungi. Polar Biol. 18:128-34.

[36] Kochkina, G.A., Ivanushkina, N.E., Akimov, V.N., Gilichinskii, D.A., Ozerskaya, S.M. (2007): Halo and psychrotolerant Geomyces fungi from Arctic cryopegs and Marine deposits. - Microbiol. 76:31-8.

[37] El-Mougith, A.A. (1993): The effect of salinity on some halophilic soil fungi. Towards the rational use of high salinity tolerant plants. - Tasks veget sci. 27:473-477. 
[38] Greiner, K., Persoh, D., Weig, A., Rambold, G. (2013): Phialosimplex salinarum, a new species of Eurotiomycetes from a hypersaline habitat. - IMA Fung. 5:161-172.

[39] Svahn, K.S., Goransson, U., El-Seedi, H., Bohlin, L., Larsson, D.G.J., Olsen, B., Chryssanthou, E. (2012): Antimicrobial activity of filamentous fungi isolated from highly antibiotic contaminated river sediment. - Infection Ecol Epidemiol. 2:11591.

[40] Suay, I., Arenal, F., Asensio, F.J., Basilio, A., Cabello, M.A., Díez, M.T., et al. (2000): Screening of basidiomycetes for antimicrobial activities. - Ant van Leeuwenhoek 78:129-139.

[41] Brunatia, M., Rojas, J.L., Sponga, F. (2009): Diversity and pharmaceutical screening of fungi from benthic mats of Antarctic lakes. Mar Geno. 2:43-50.

[42] Singh, S.M., Singh, S.K., Yadav, L.S., Singh, P.N., Ravindra, R. (2012): Filamentous Soil Fungi from Ny-Ålesund, Spitsbergen, and screening for extracellular enzymes. Arctic. 65: 45-55.

[43] Singh, S.K., Singh, P.N., Sharma, P.K. (2014): Pigment, fatty acid and extracellular enzyme analysis of fungal strain Thelebolus microspores from Larsemann Hills, Antarctica. - Pol Record 50:31-36.

[44] Fenice, M., Selbmann, L., Zucconi, L., Onofri, S. (1997): Production of extracellular enzymes by Antarctic fungal strains. - Polar Biol. 17:275-80. 


\section{APPENDIX}

Supplementary Table 1. Colony morphology and microscopic characteristics of fungal isolates on SDA

\begin{tabular}{|c|c|c|c|c|c|}
\hline \multirow[t]{2}{*}{ Isolate } & \multirow{2}{*}{$\begin{array}{c}\text { Sample } \\
\text { form }\end{array}$} & \multirow{2}{*}{$\begin{array}{c}\text { Temperature } \\
\left({ }^{\circ} \mathrm{C}\right)\end{array}$} & \multicolumn{2}{|c|}{ Colony morphology } & \multirow{2}{*}{$\begin{array}{c}\text { Microscopic } \\
\text { characteristics }\end{array}$} \\
\hline & & & Front & Reverse & \\
\hline $\mathbf{H S}_{\mathbf{1}}$ & Sediment & 15 & $\begin{array}{l}\text { Cottony, } \\
\text { initially } \\
\text { yellow to } \\
\text { green then } \\
\text { turned to sea } \\
\text { green with } \\
\text { dim gray } \\
\text { edges }\end{array}$ & $\begin{array}{l}\text { Dark brown } \\
\text { center with } \\
\text { saddle } \\
\text { brown edges }\end{array}$ & $\begin{array}{l}\text { Hyphae hyaline to } \\
\text { pale yellow and } \\
\text { septate, scattered } \\
\text { and erect } \\
\text { conidiophores, and } \\
\text { branched conidia }\end{array}$ \\
\hline $\mathbf{H S}_{\mathbf{2}}$ & Sediment & 15 & $\begin{array}{l}\text { Cottony, } \\
\text { initially dry } \\
\text { mucoid, } \\
\text { sandy brown } \\
\text { then turned } \\
\text { to pale } \\
\text { goldenrod } \\
\text { with light } \\
\text { yellow } \\
\text { margins }\end{array}$ & $\begin{array}{l}\text { Saddle } \\
\text { brown center } \\
\text { and khaki } \\
\text { edges }\end{array}$ & $\begin{array}{l}\text { Spores are hyaline, } \\
\text { conidia vary in } \\
\text { shape and size, } \\
\text { asci cylindrical } \\
\text { shape. }\end{array}$ \\
\hline $\mathbf{H S}_{\mathbf{3}}$ & Ice & 15 & $\begin{array}{l}\text { Mucoid, } \\
\text { lemon } \\
\text { chippon } \\
\text { center with } \\
\text { off-white } \\
\text { margins }\end{array}$ & $\begin{array}{l}\text { Off-white to } \\
\text { yellow } \\
\text { center and } \\
\text { off-white } \\
\text { margins }\end{array}$ & $\begin{array}{l}\text { Round to ovoid } \\
\text { shaped spores, } \\
\text { branched or chain } \\
\text { conidia and } \\
\text { scattered }\end{array}$ \\
\hline $\mathbf{H S}_{4}$ & Ice & 15 & $\begin{array}{l}\text { Dry mucoid, } \\
\text { deep } \\
\text { burlywood } \\
\text { center with } \\
\text { off-white } \\
\text { margins }\end{array}$ & $\begin{array}{l}\text { Sandy } \\
\text { brown to } \\
\text { brown center } \\
\text { and off- } \\
\text { white } \\
\text { margins }\end{array}$ & $\begin{array}{l}\text { Conidiophores } \\
\text { hyaline, septate } \\
\text { hyphae, ovoid } \\
\text { shaped conidia }\end{array}$ \\
\hline $\mathbf{H S}_{5}$ & Ice & 15 & $\begin{array}{l}\text { Velvety, } \\
\text { initially dark } \\
\text { olive green } \\
\text { with light } \\
\text { yellow edges } \\
\text { then turned } \\
\text { to black to } \\
\text { dark green } \\
\text { with white } \\
\text { surface }\end{array}$ & $\begin{array}{l}\text { Black center } \\
\text { with Off- } \\
\text { white edges }\end{array}$ & $\begin{array}{l}\text { Branched, pale } \\
\text { olivaceous brown } \\
\text { hyphae, conidia } \\
\text { ellipsoidal to } \\
\text { limoni-form, } \\
\text { smooth-walled or } \\
\text { slightly verrucose, } \\
\text { olivaceous brown }\end{array}$ \\
\hline
\end{tabular}




\begin{tabular}{|c|c|c|c|c|c|}
\hline $\mathbf{H S}_{6}$ & Water & 15 & $\begin{array}{l}\text { Velvety, } \\
\text { initially dark } \\
\text { olive green } \\
\text { with light } \\
\text { yellow edges } \\
\text { then turned } \\
\text { to black to } \\
\text { dark green }\end{array}$ & $\begin{array}{l}\text { Black center } \\
\text { with Off- } \\
\text { white edges }\end{array}$ & $\begin{array}{l}\text { Subglobose to } \\
\text { broadly ellipsoid } \\
\text { conidiophores, } \\
\text { conidia are less } \\
\text { branched and } \\
\text { darker in nature }\end{array}$ \\
\hline $\mathbf{H S}_{7}$ & Water & 15 & $\begin{array}{l}\text { Cottony, } \\
\text { initially } \\
\text { white then } \\
\text { surface } \\
\text { turned to } \\
\text { green }\end{array}$ & $\begin{array}{l}\text { Off-white to } \\
\text { yellow } \\
\text { center with } \\
\text { dark green } \\
\text { margins }\end{array}$ & $\begin{array}{l}\text { Phialides straight } \\
\text { or sinuous and } \\
\text { globose to } \\
\text { subglobose } \\
\text { chlamydospores }\end{array}$ \\
\hline $\mathbf{H S}_{8}$ & Water & 15 & $\begin{array}{l}\text { Mucoid, } \\
\text { lemon } \\
\text { chippon } \\
\text { center with } \\
\text { off-white } \\
\text { margins }\end{array}$ & $\begin{array}{l}\text { Off-white to } \\
\text { yellow } \\
\text { center and } \\
\text { off-white } \\
\text { margins }\end{array}$ & $\begin{array}{l}\text { Spores are round } \\
\text { to ovoid shaped, } \\
\text { branched or chain } \\
\text { hyphae and } \\
\text { scattered }\end{array}$ \\
\hline $\mathbf{H S}_{9}$ & Water & 15 & $\begin{array}{l}\text { Cottony, } \\
\text { initially dry } \\
\text { mucoid, } \\
\text { sandy brown } \\
\text { then turned } \\
\text { to pale } \\
\text { goldenrod } \\
\text { with light } \\
\text { yellow } \\
\text { margins }\end{array}$ & $\begin{array}{l}\text { Saddle } \\
\text { brown center } \\
\text { and khaki } \\
\text { edges }\end{array}$ & $\begin{array}{l}\text { Spores are hyaline, } \\
\text { conidia vary in } \\
\text { shape and size, } \\
\text { asci cylindrical } \\
\text { shape. }\end{array}$ \\
\hline $\mathbf{L S}_{\mathbf{1}}$ & Sediment & 4 & $\begin{array}{l}\text { Cottony, } \\
\text { initially } \\
\text { mucoid, } \\
\text { brown then } \\
\text { turned to } \\
\text { goldenrod } \\
\text { with light } \\
\text { yellow } \\
\text { margins } \\
\end{array}$ & $\begin{array}{l}\text { Brown } \\
\text { center and } \\
\text { khaki edges }\end{array}$ & $\begin{array}{l}\text { Spores are hyaline, } \\
\text { conidia vary in } \\
\text { shape and size, } \\
\text { asci cylindrical } \\
\text { shape. }\end{array}$ \\
\hline $\mathbf{L S}_{2}$ & Sediment & 4 & $\begin{array}{l}\text { Mucoid, } \\
\text { lemon } \\
\text { chippon } \\
\text { center with } \\
\text { off-white } \\
\text { margins }\end{array}$ & $\begin{array}{l}\text { Off-white to } \\
\text { yellow } \\
\text { center and } \\
\text { off-white } \\
\text { margins }\end{array}$ & $\begin{array}{l}\text { Round to ovoid } \\
\text { shaped spores, } \\
\text { branched or chain } \\
\text { conidia and } \\
\text { scattered }\end{array}$ \\
\hline
\end{tabular}




\begin{tabular}{|c|c|c|c|c|c|}
\hline $\mathbf{L S}_{\mathbf{3}}$ & Sediment & 4 & $\begin{array}{l}\text { Mucoid, } \\
\text { light } \\
\text { goldenrod } \\
\text { yellow center } \\
\text { with off- } \\
\text { white } \\
\text { margins }\end{array}$ & $\begin{array}{l}\text { Off-white to } \\
\text { yellow } \\
\text { center and } \\
\text { off-white } \\
\text { margins }\end{array}$ & $\begin{array}{l}\text { Ellipsoid to } \\
\text { cylindrical } \\
\text { ascospores, } \\
\text { hyphae bundantly } \\
\text { septate, branched, } \\
\text { rich in oleaginous } \\
\text { globules }\end{array}$ \\
\hline $\mathbf{L S}_{4}$ & Ice & 4 & $\begin{array}{l}\text { Cottony, } \\
\text { deep brown } \\
\text { center with } \\
\text { white margin }\end{array}$ & $\begin{array}{l}\text { Black to } \\
\text { brown center } \\
\text { and light } \\
\text { brown } \\
\text { margins }\end{array}$ & $\begin{array}{l}\text { Conidia are } \\
\text { spherical to } \\
\text { globose shaped, } \\
\text { septate hyphae and } \\
\text { conidial heads are } \\
\text { globose to ovoid }\end{array}$ \\
\hline $\mathbf{L S}_{5}$ & Ice & 4 & $\begin{array}{l}\text { Mucoid, pale } \\
\text { goldenrod } \\
\text { center with } \\
\text { off-white } \\
\text { edges }\end{array}$ & $\begin{array}{l}\text { Off-white to } \\
\text { yellow } \\
\text { center and } \\
\text { off-white } \\
\text { margins }\end{array}$ & $\begin{array}{l}\text { Ellipsoid shaped } \\
\text { ascospores, } \\
\text { hyphae septate, } \\
\text { branched, rich in } \\
\text { oleaginous } \\
\text { globules }\end{array}$ \\
\hline $\mathbf{L S}_{6}$ & Ice & 4 & $\begin{array}{l}\text { Dry mucoid, } \\
\text { deep } \\
\text { burlywood } \\
\text { center with } \\
\text { off-white } \\
\text { margins }\end{array}$ & $\begin{array}{l}\text { Sandy } \\
\text { brown to } \\
\text { brown center } \\
\text { and off- } \\
\text { white } \\
\text { margins }\end{array}$ & $\begin{array}{l}\text { Conidiophores } \\
\text { hyaline, septate } \\
\text { hyphae, ovoid } \\
\text { shaped conidia }\end{array}$ \\
\hline $\mathbf{L S}_{7}$ & Water & 4 & $\begin{array}{l}\text { Mucoid, } \\
\text { salmon } \\
\text { center and } \\
\text { off-white } \\
\text { margins } \\
\end{array}$ & $\begin{array}{l}\text { Off-white to } \\
\text { yellow } \\
\text { center and } \\
\text { off-white } \\
\text { margins }\end{array}$ & $\begin{array}{l}\text { Spores are globose } \\
\text { to ovoid shape, no } \\
\text { true or hyphae } \\
\text { pseudohyphae } \\
\text { observed }\end{array}$ \\
\hline $\mathbf{L S}_{8}$ & Water & 4 & $\begin{array}{l}\text { Mucoid, dark } \\
\text { salmon } \\
\text { center and } \\
\text { off-white } \\
\text { edges }\end{array}$ & $\begin{array}{l}\text { Burlywood } \\
\text { center with } \\
\text { off-white } \\
\text { margins }\end{array}$ & $\begin{array}{l}\text { Hyaline and } \\
\text { septate hyphae, } \\
\text { round to ovoid } \\
\text { shaped spores and } \\
\text { in scattered form }\end{array}$ \\
\hline
\end{tabular}

